\title{
Development of the Food List for a Brazilian Total Diet Study
}

\author{
Roseane Pagliaro AVEGLIANO ${ }^{1}$, Vera Akiko MAIHARA ${ }^{1 \star}$, Fábio Fernando da SILVA²
}

\begin{abstract}
The objective of this paper is to establish a methodology for the Food List for the southeastern region of Brazil, according to the Total Diet Study (TDS) harmonized methodology at international level. The Food List can provide data for a further TDS with evaluation of essential and toxic element dietary intakes by food analysis in laboratories. The food consumption data source used was from 2008-2009 Household Budget Survey, by the Brazilian Institute of Geography and Statistics. The Food List was composed of 82 food items grouped into 19 food groups. It reflects $100 \%$ of the daily individual food consumption inside and outside Brazilian southeastern population households. According to the recommendation that each country should carry out their own TDS and the TDS methodology used, the Food List construction can contribute to the Food List of other Brazilian regions and other countries, besides allowing the TDS development. Additionally, the Food List showed the typical diet for the southeastern region of Brazil.
\end{abstract}

Keywords: Total Diet Study (TDS); dietary intakes; population food intake; food grouping.

Practical Application: The paper establishes a Food List, which is the central part of Total Diet Study (TDS).

\section{Introduction}

The Total Diet Study (TDS) is an approach to estimate and monitor dietary exposures to chemical residues, potential harmful substances, such as contaminants and beneficial substances, such as nutrients, elements, or micronutrients that can be present in food in levels that can adversely affect the health of consumers (European Food Safety Authority et al., 2011b; World Health Organization, 1985). TDS is carried out by the selection of foods based on food consumption data that are representative of the overall diet of a certain population; the development of the Food List; the sampling and the kitchen preparation of the samples as they are normally consumed; the analysis in laboratories, and the combination of the analytical results with food consumption data. Since the food is prepared as ready to eat, consequently, chemical changes during preparation are considered. Because dietary habits are different in each country, the World Health Organization (WHO) has encouraged countries to carry out their own TDS (European Food Safety Authority et al., 2011b; World Health Organization, 1985, 1999, 2002, 2005, 2006). TDS has been conducted in different countries since 1961. WHO published a detailed guideline in 1985 (World Health Organization, 1985) to support the TDS development. In order to provide harmonization in the TDS approach and allow the comparability of the results among different TDS, the Working Group of experts on TDS developed a guidance document (European Food Safety Authority et al., 2011a, b).

The Food List is the central part of the TDS because it determines the types and quantities of foods that are collected for the study. The Food List was previously named as Market Basket (World Health Organization, 1985). Since TDS is based on an entire diet, $80-95 \%$ of the diet foods should be included, at least $90 \%$ as close as possible to the entire population diet (European Food Safety Authority et al., 2011b).

There are 2 main different approaches to joint food items and elaborate the Food List: Individual and Mixed food approach (European Food Safety Authority et al., 2011a, b; World Health Organization, 1985). The former combines individual food items, in different varieties of the same type of food; the latter groups different types of foods from the same food group, combining foods with similar levels of the chemical substances to those analyzed (European Food Safety Authority et al., 2011b; World Health Organization, 1985). Due to the relatively smaller number of the food samples to be analyzed in the laboratory, the Mixed Food approach is less expensive and more feasible than the Individual approach. The amount of the food items in the food group is proportional to its approximate share in a typical diet.

The Food List is composed by a limited group of foods that are representative of those foods normally consumed by the TDS population, obtained through reliable and representative food consumption data from mainly National Household Budget Surveys (European Food Safety Authority et al., 2011b; World Health Organization, 1985).

The 2008-2009 Household Budget Survey (HBS) by the Brazilian Institute of Geography and Statistics (IBGE), which is the fifth HBS in Brazil, sampled households in 5 major regions

Received 12 Jan., 2015

Accepted 16 Feb., 2015

${ }^{1}$ Laboratório de Análise por Ativação Neutrônica - LAN, Instituto de Pesquisas Energéticas e Nucleares - IPEN, Comissão Nacional de Energia Nuclear - CNEN/SP, São Paulo, SP, Brazil

${ }^{2}$ Universidade de São Paulo - USP, São Paulo, SP, Brazil

*Corresponding author: vmaihara@ipen.br 
of the country (Instituto Brasileiro de Geografia e Estatística, $2010,2011)$. The 2008-2009 HBS includes, firstly, personal food consumption out of the household, by Analysis of Personal Food Consumption for Brazilian regions. In the southeastern region, among 14,078 households researched, 3,064 were randomly selected as the sub-sample for the Analysis of Personal Food Consumption, to obtain data of 7,302 inhabitants aged 10 or over, in the urban and rural areas of the region. All the food consumed inside and outside home was registered by each resident for two non-consecutive days, throughout twenty-four hours of the day (Instituto Brasileiro de Geografia e Estatística, 2011).

The objective of this paper is to establish a methodology for the TDS Food List for the southeastern region of Brazil, according to the TDS harmonized methodology at international level, in order to provide data for a further TDS, with evaluation of essential and toxic element dietary intakes, by laboratory food analysis.

\section{Materials and methods}

The methodology to establish the Food List was based mainly on European Food Safety Authority et al. (2011b) and World Health Organization (1985), and on previous Brazilian TDSs (Avegliano, 2009; Avegliano et al., 2008, 2011; Avegliano \& Maihara, 2014).

The food consumption data source was from Brazilian 2008-2009 HBS, which is considered a reliable and representative data source. The southeastern region was chosen for this work because it includes São Paulo State, which has been previously studied in Brazil. Besides, the southeastern region has $80,005,167$ inhabitants, representing $42 \%$ of the Brazilian population. The São Paulo State population represents 51\% of the southeastern region population.

The Analysis of Personal Food Consumption in the southeastern region was the source of food selection for the Food List. The Food List is based on the individual consumption, in and out the household, providing data about total daily consumption. The intake of 1,121 food items was reported and they were grouped into 103 food items, per capita, of average food consumption by IBGE (Instituto Brasileiro de Geografia e Estatística, 2011).

The Mixed Food approach was chosen to pool the related foods in the construction of the Food List and involved several steps in order to be the most representative as possible, because of the relative importance of food sources as for chemical substances, such as essential elements and contaminants and, thus, aiming at the general goal of the TDS. For elaboration of the Food List, five steps were followed:

\subsection{First step: selection of foods}

The selection of foods for the Brazilian southeastern region Food List is based on per capita average food consumption from 103 food items, in and out of the sub-sample of the households (Instituto Brasileiro de Geografia e Estatística, 2011). At this step, the food items were organized into 21 major groups or food groups, according to the IBGE (Instituto Brasileiro de Geografia e Estatística, 2011) group classification: Cereals; Beans; Vegetables; Legumes; Roots; Fruits; Nuts and Seeds;
Flour and pasta; Bakery products; Cakes; Biscuits; Meat; Eggs; Dairy products; Sweets; Oils and fats; Beverages; Pizza, snacks and sandwiches; Soups; Sauces; and Mixtures.

The foods were considered in terms of per capita average food consumption, in g/day, representing $100 \%$ of the daily total weight of the foods consumed by the population. The average of the total daily food consumption amount is 1,606.60 grams.

\subsection{Second step: food group sub-division}

The IBGE pooling is based on similar food nutritional composition or their main ingredient similarity. As such, chicken (poultry), beef, pork and fish are classified in the meat food group. As this group may contain significant differences of nutrients and contaminants, additional meat subgroups were created for this study. The meat group was divided into 5 groups: chicken (poultry), beef, pork, fish, industrialized meat/offal. Consequently, the Food List resulted in 25 food groups. The total daily amount, $1,606.60 \mathrm{~g}$, of food consumption divided into 103 food items is the same as in the First Step of the Food List.

\subsection{Third step: complementing the Food List}

In per capita average food consumption for Brazil's southeastern region, by IBGE, the information about consumption of salt and wheat flour was not available.

As salt is known as a significant source of sodium, it was included as an additional food and it was considered as a food group, consisting of only one food item. The amount of salt consumed daily has been estimated as $4.6 \mathrm{~g} /$ day, even though this datum refers only to the acquisition for consumption by the household (Instituto Brasileiro de Geografia e Estatística, 2010).

Wheat flour was included because of its importance in providing essential elements, mainly iron, as shown in previous Brazilian TDS, since this flour is fortified with this element (Avegliano, 2009; Avegliano et al., 2011). The estimated amount of wheat flour consumed was estimated at $6.77 \mathrm{~g} /$ day, for household acquisition and consumption (Instituto Brasileiro de Geografia e Estatística, 2010). Wheat flour was included in the food group under Flours.

With the inclusion of salt and wheat flour, the Food List shows 1,617.97 grams of per capita daily food consumption and 105 food items. With the inclusion of the salt food group, the Food List increased to 26 groups.

\subsection{Fourth step: reducing number of food items}

Among the 105 items, 23 food items did not have descriptive information and were classified as "Others types", "Others", and so on.

Therefore, the missing information was obtained by other means: it was assumed for this study that the amount of these undefined food items was included, proportionally, in other components of the same group, in order to maintain 1,617.97 grams per capita and 26 food groups of the Food List. Thus, the Food List was reduced to 82 food items. 


\subsection{Fifth step: pooling food groups}

In order to reduce the number of food groups, and consequently the number of samples for future laboratory analysis, the food groups with similar nutritional composition or similarity of the main ingredients of their food items were pooled together (Table 1).

After the aggregation of the food groups, the Food List resulted in 19 food groups, including 82 food items and weighing 1,617.97g. Once the Food List is established, future TDS will have to prepare the foods as they are consumed in the household to estimate the consumption of chemical elements in ready-to-consume foods. Each individual food item should be in the same proportions determined in its food group of the Food List. The sampling and kitchen preparation are described in Avegliano (2009), Avegliano et al. $(2008,2011)$ and Avegliano \& Maihara (2014).

\section{Results and discussion}

Despite the fact that TDSs are conducted in several countries worldwide, there is just one previous Brazilian TDS developed for São Paulo State, Brazil, from the 2002-2003 HBS data (Avegliano, 2009; Avegliano et al., 2008, 2011; Avegliano \& Maihara, 2014). The first Food List, former Market Basket, was based on the acquisition of food for consumption in the households of the State population, whereas the consumption out the household was not available. As a consequence, the weight of this Market Basket was below the real daily consumption

As the result of this current study, Table 2 shows the amounts of foods in proportions based on the amount in a typical diet of the Brazilian southeastern region. The Food List weighs $1,617.97$ grams, which is the medium daily consumption of this region population.

The present Food List is far more complete than the previous Brazilian TDS. Food groups from the previous TDS were limited to $72 \%$ of the weight of the foods acquired for consumption at more than 2g/day/person, in households of São Paulo State, while this TDS includes $100 \%$ of the weight of the foods consumed in and out of households of the southeastern region. Previously, the Food List, the former Market Basket, was composed of 71 food items, while the current Food List presents 82 food items. This means more available food items to be analyzed for chemical

Table 1. Data of initial food groups and food groups after aggregation.

\begin{tabular}{|c|c|c|c|}
\hline \multicolumn{2}{|c|}{ Initial food groups } & \multicolumn{2}{|c|}{ Pooled food groups } \\
\hline Names & Quantity & Names & Quantity \\
\hline $\begin{array}{c}\text { Vegetables; Legumes; } \\
\text { Roots }\end{array}$ & 3 & Vegetables & 1 \\
\hline $\begin{array}{c}\text { Flours and pasta; Bakery } \\
\text { products }\end{array}$ & 2 & $\begin{array}{l}\text { Flours, pasta and } \\
\text { bakery products }\end{array}$ & 1 \\
\hline Cakes; Biscuits & 2 & Cakes and biscuits & 1 \\
\hline $\begin{array}{l}\text { Pizza, snacks and } \\
\text { sandwiches; Soups; } \\
\text { Sauces; Mixtures }\end{array}$ & 4 & $\begin{array}{c}\text { Pizza, snacks, } \\
\text { sandwiches, } \\
\text { soups, sauces and } \\
\text { mixtures }\end{array}$ & 1 \\
\hline
\end{tabular}

Table 2. Food List and percentage of weight of food items in food groups.

\begin{tabular}{|c|c|c|c|}
\hline Food groups & Food items & $\begin{array}{c}\text { Daily } \\
\text { consumption } \\
\text { per capita (g) }\end{array}$ & $\begin{array}{l}\% \text { weight in } \\
\text { food groups }\end{array}$ \\
\hline \multirow[t]{3}{*}{1 - Cereals } & polished rice & 177.27 & 92.86 \\
\hline & corn & 7.47 & 3.91 \\
\hline & whole rice & 6.16 & 3.23 \\
\hline \multirow[t]{2}{*}{2 - Beans } & beans & 223.40 & 99.91 \\
\hline & green beans & 0.20 & 0.09 \\
\hline \multirow[t]{12}{*}{ 3- Vegetables } & potato & 24.01 & 30.59 \\
\hline & cauliflower & 14.64 & 18.65 \\
\hline & tomato & 12.09 & 15.40 \\
\hline & lettuce & 10.91 & 13.89 \\
\hline & cassava & 3.93 & 5.01 \\
\hline & pumpkin & 3.83 & 4.87 \\
\hline & cabbage & 3.16 & 4.02 \\
\hline & carrot & 1.99 & 2.53 \\
\hline & chayote & 1.84 & 2.34 \\
\hline & sweet potato & 0.93 & 1.19 \\
\hline & french fries & 0.72 & 0.92 \\
\hline & cucumber & 0.46 & 0.58 \\
\hline \multirow[t]{11}{*}{4 - Fruits } & orange & 24.07 & 29.39 \\
\hline & banana & 20.15 & 24.60 \\
\hline & apple & 13.61 & 16.62 \\
\hline & papaya & 7.51 & 9.18 \\
\hline & tangerine & 4.57 & 5.59 \\
\hline & water melon & 3.59 & 4.39 \\
\hline & mango & 2.72 & 3.32 \\
\hline & fruit salad & 2.07 & 2.53 \\
\hline & acai berry & 1.20 & 1.46 \\
\hline & grape & 1.20 & 1.46 \\
\hline & pineapple & 1.20 & 1.46 \\
\hline $\begin{array}{l}5 \text { - Nuts and } \\
\text { seeds }\end{array}$ & nuts and seeds & 0.2 & 100.00 \\
\hline \multirow{9}{*}{$\begin{array}{l}6 \text { - Flours, pasta } \\
\text { and bread }\end{array}$} & french loaf & 52.10 & 48.12 \\
\hline & $\begin{array}{l}\text { pasta based } \\
\text { mixtures }\end{array}$ & 33.80 & 31.22 \\
\hline & wheat flour & 6.77 & 6.25 \\
\hline & $\begin{array}{l}\text { instantaneous } \\
\text { pasta }\end{array}$ & 6.60 & 6.10 \\
\hline & pasta & 4.90 & 4.53 \\
\hline & stuffing & 1.50 & 1.39 \\
\hline & breakfast cereal & 1.10 & 1.02 \\
\hline & cassava flour & 0.80 & 0.74 \\
\hline & $\begin{array}{c}\text { whole wheat } \\
\text { bread }\end{array}$ & 0.70 & 0.65 \\
\hline \multirow{4}{*}{$\begin{array}{l}7 \text { - Cakes and } \\
\text { biscuits }\end{array}$} & cakes & 14.60 & 48.83 \\
\hline & salted biscuit & 6.98 & 23.35 \\
\hline & stuffed cookies & 4.31 & 14.42 \\
\hline & cookie & 4.00 & 13.39 \\
\hline $\begin{array}{l}\text { 8-Cattle } \\
\text { meat(beef) }\end{array}$ & rump & 67.10 & 100.00 \\
\hline 9 - Pork & slender leg & 9.70 & 100.00 \\
\hline 10 - Poultry & chicken & 33.00 & 100.00 \\
\hline \multirow[t]{3}{*}{11 - Fish } & sardine & 11.80 & 79.17 \\
\hline & coldfish & 2.69 & 18.06 \\
\hline & sardine in oil & 0.41 & 2.78 \\
\hline
\end{tabular}


Table 2. Continued...

\begin{tabular}{|c|c|c|c|}
\hline Food groups & Food items & $\begin{array}{c}\text { Daily } \\
\text { consumption } \\
\text { per capita }(\mathrm{g})\end{array}$ & $\begin{array}{l}\% \text { weight in } \\
\text { food groups }\end{array}$ \\
\hline \multirow{5}{*}{$\begin{array}{l}12 \text { - } \\
\text { Industrialized } \\
\text { meat and offal }\end{array}$} & sausage & 5.74 & 40.16 \\
\hline & cooked sausage & 3.60 & 25.20 \\
\hline & bovine liver & 1.91 & 13.39 \\
\hline & mortadella & 1.58 & 11.02 \\
\hline & ham & 1.46 & 10.24 \\
\hline \multirow{6}{*}{$\begin{array}{l}13 \text { - Eggs } \\
14 \text { - Dairy } \\
\text { products }\end{array}$} & chicken egg & 9.90 & 100.00 \\
\hline & $\begin{array}{l}\text { pausterized cow } \\
\text { whole milk }\end{array}$ & 39.89 & 52.49 \\
\hline & natural yogurt & 11.59 & 15.25 \\
\hline & white cheese & 9.14 & 12.02 \\
\hline & fruit smoothie & 9.03 & 11.88 \\
\hline & low fat milk & 6.35 & 8.36 \\
\hline \multirow[t]{5}{*}{15 - Sweets } & pudding & 8.08 & 33.94 \\
\hline & ice cream & 7.21 & 30.30 \\
\hline & chocolate & 5.19 & 21.82 \\
\hline & $\begin{array}{c}\text { powder } \\
\text { chocolate }\end{array}$ & 1.73 & 7.27 \\
\hline & $\begin{array}{c}\text { crystalized fruit } \\
\text { sweet }\end{array}$ & 1.59 & 6.67 \\
\hline 16 - Oils and fats & soil oil & 7.60 & 100.00 \\
\hline \multirow[t]{9}{*}{17 - Beverages } & coffee & 218.93 & 38.84 \\
\hline & fruit juice & 149.34 & 26.49 \\
\hline & coke soft drink & 113.64 & 20.16 \\
\hline & beer & 36.42 & 6.46 \\
\hline & milk beverages & 28.49 & 5.05 \\
\hline & tea & 11.80 & 2.09 \\
\hline & soy beverages & 2.65 & 0.47 \\
\hline & wine & 1.63 & 0.29 \\
\hline & $\begin{array}{l}\text { alcoholic } \\
\text { beverages }\end{array}$ & 0.81 & 0.14 \\
\hline \multirow{7}{*}{$\begin{array}{l}18 \text { - Pizza, } \\
\text { snacks, } \\
\text { sandwiches, } \\
\text { soups, sauces } \\
\text { and mixtures }\end{array}$} & soups & 42.30 & 52.81 \\
\hline & sandwiches & 14.30 & 17.85 \\
\hline & snacks & 12.60 & 15.73 \\
\hline & mixture & 4.80 & 5.99 \\
\hline & pizzas & 4.70 & 5.87 \\
\hline & appetizer & 0.70 & 0.87 \\
\hline & tomato sauce & 0.70 & 0.87 \\
\hline 19 - Salt & salt & 4.6 & 100.00 \\
\hline TOTAL & & $1,617.97$ & \\
\hline
\end{tabular}

substances and provide more reasonable data from personal food consumption than the acquisition data used for the previous TDS (Avegliano, 2009; Avegliano et al., 2008, 2011; Avegliano \& Maihara, 2014).

When comparing the compilation of the TDS Food List among countries, different TDS experiences arise. The 82 food items included in the Brazilian Food List are less than 96 food items from the Australian TDS (European Food Safety Authority et al., 2011a; Food Standards Australia New Zealand, 2011), 265-280 food items from the US TDS (European Food Safety Authority et al., 2011a, b; Egan et al., 2002, 2007) and 121-123 food items from the New Zealand TDS (European Food Safety Authority et al.,
Table 3. Relative participation of food groups in the Food List.

\begin{tabular}{lcc}
\hline \multicolumn{1}{c}{ Food groups } & $\begin{array}{c}\text { Food group } \\
\text { weight }(\mathrm{g})\end{array}$ & $\begin{array}{c}\% \\
\text { participation }\end{array}$ \\
\hline Beverages & 563.70 & 34.84 \\
Beans & 223.60 & 13.82 \\
Cereals & 190.90 & 11.80 \\
Flours, pasta and bakery products & 108.27 & 6.69 \\
Fruits & 81.90 & 5.06 \\
Pizza, snacks, sandwiches, soups, sauces, & 80.10 & 4.95 \\
mixtures & & \\
Vegetables & 78.50 & 4.85 \\
Dairy products & 76.00 & 4.70 \\
Cattle meat ( beef) & 67.10 & 4.15 \\
Poultry & 33.00 & 2.04 \\
Cakes and biscuits & 29.90 & 1.85 \\
Sweets & 23.80 & 1.47 \\
Fish & 14.90 & 0.92 \\
Industrialized meat and offal & 14.30 & 0.88 \\
Eggs & 9.90 & 0.61 \\
Pork & 9.70 & 0.60 \\
Oils and fats & 7.60 & 0.47 \\
Salt & 4.60 & 0.28 \\
Nuts and seeds & 0.20 & 0.01 \\
Total & $1,617.97$ & 100 \\
\hline & & \\
\hline
\end{tabular}

2011a; Ministry of Agriculture and Forestry, 2011). However, Australia, the USA, and New Zealand have been conducting their TDSs by government agencies or national organizations and cover a wide range of items.

The quantity of 19 food groups of this Brazilian TDS is also fewer than the 140 TDS food groups in Canada (Health Canada, 2009), 48 in China (World Health Organization, 1999, 2002, 2005), 41-44 in France (French agency for food, environmental and occupational health \& safety, 2011; Sirot et al., 2009; Arnich et al.,2012) and 143 in the Czech Republic (World Health Organization, 1999, 2002, 2005, 2006), nevertheless all of them are under national institutes or governmental agencies. On the other hand, the Brazilian Food list is close to the 17 food groups in Chile (Munõz et al., 2005), 11-16 food groups in Spain (World Health Organization, 1999, 2005; Llobet et al., 2003), 12 food groups in Italy (European Food Safety Authority et al., 2011a, b; Lombardi-Boccia et al., 2003; Turrini \& Lombardi-Boccia, 2002), 14 in Japan (World Health Organization, 1999, 2006), 20 in the United Kingdom (European Food Safety Authority et al., 2011b) and 21 in the Lebanon (Nasreddine et al., 2006, 2010). These TDSs were performed as part of research projects for TDSs development (European Food Safety Authority et al., 2011a).

Table 3 shows the relative participation of each food group to the Brazilian Food List, considering their contribution in percentage of their weight.

According to Tables 2 and 3, Beverages were the most consumed food group, with coffee consumption being $218.93 \mathrm{~g}$, which is $13.51 \%$ of the total Food List. The other most consumed food items are beans $(223.60 \mathrm{~g}$ ) and rice $(183.43 \mathrm{~g})$, representing $13.82 \%$ and $11.34 \%$ of the total Food List, respectively. The food 
groups containing food items from vegetable sources corresponded to $35.54 \%$ of the food groups, while the food groups from animal sources represented only $13.90 \%$ of the Food List $(8.59 \%$ to food items with several types of meat; $0.61 \%$ for eggs, and $4.70 \%$ for dairy products). The food groups based, mainly, on Flour showed $13.49 \%$ of participation, which it is about the same percentage for Meats, Eggs, and Dairy products food groups (13.90\%). Oils, fats and salt presented low participation $(0.75 \%)$. Nonetheless, salt was considered merely for consumption in households.

The Food List presented in this study represents $100 \%$ of the foods consumed, without considering the intake limits of grams consumed, similarly to the American TDS. The French TDS represents $88-90 \%$ of the average population diet; the Spanish TDS covers $90 \%$, considering food consumed more than $1 \mathrm{~g} / \mathrm{d} /$ person; and Italian TDS shows food consumed more than $1 \mathrm{~g} / \mathrm{d} /$ person.

\section{Conclusions}

A Food List for the southeastern region of Brazil was developed, in order to provide data for a Brazilian TDS. Since Brazilian 2008-2009 HBS provides data for the whole country by major regions this Food List can be adapted for other Brazilian regions, considering the foods that are commonly consumed in each region. Additionally, the Food List showed the typical diet for the southeastern region of Brazil.

Finally, as the Food List construction described follows TDS harmonized methodology at international level, it can be also useful for countries with no previous TDS experience and, consequently, without any Food List available.

\section{Acknowledgements}

The authors would like to thank the Fapesp (Process number 2013/08869-6), CNPq (30296/2012-3) and IPEN/CNEN-SP for financial support.

\section{References}

Arnich, N., Sirot, V., Rivière, G., Jean, J., Noël, L., Guérin, T., \& Leblanc, J.-C. (2012). Dietary exposure to trace elements and health risk assessment in the 2nd French Total Diet Study. Food and chemical toxicology: an international journal published for the British Industrial Biological Research Association, 50(7), 2432-2449. http://dx.doi. org/10.1016/j.fct.2012.04.016. PMid:22521625

Avegliano, R. P. (2009). Estudo de Dieta Total no Estado de São Paulo: Estimativa de ingestão dietética de elementos tóxicos (Arsênio e Cádmio) e essenciais (Cálcio, Cromo, Ferro, Selênio, Sódio, Potássio e Zinco) (Tese de Doutorado). Instituto de Pesquisas Energéticas e Nucleares, São Paulo.

Avegliano, R. P., \& Maihara, V. A. (2014). Total Diet Study: Mg and Mn content estimation of a Market Basket of São Paulo state (Brazil) by Instrumental Neutron Activation. Journal of Radioanalytical and Nuclear Chemistry, 299(1), 781-785. http://dx.doi.org/10.1007/ s10967-013-2699-0.

Avegliano, R. P., Maihara, V. A., \& Silva, F. F. (2008). Total diet study in the state of São Paulo, Brazil, to estimate the dietary intakes of toxic and essential elements: development of the Market Basket. Ciência e Tecnologia de Alimentos, 28(1), 90-97. http://dx.doi.org/10.1590/ S0101-20612008000100014.

Avegliano, R. P., Maihara, V. A., \& Silva, F. F. (2011). A Brazilian Total Diet Study: Evaluation of essential elements. Journal of Food Composition and Analysis, 24(7), 1009-1016. http://dx.doi. org/10.1016/j.jfca.2011.01.017.

Egan, S. K., Bolger, P. M., \& Carrington, C. D. (2007). Update of US FDA's Total Diet Study food list and diets. Journal of Exposure Science \& Environmental Epidemiology, 17(6), 573-582. http://dx.doi. org/10.1038/sj.jes.7500554. PMid:17410117

Egan, S. K., Tao, S. S.-H., Pennington, J. A. T., \& Bolger, P. M. (2002). US Food and Drug Administration's Total Diet Study: intake of nutritional and toxic elements, 1991-96. Food Additives and Contaminants, 19(2), 103-125. http://dx.doi.org/10.1080/02652030110071354. PMid:11824417

European Food Safety Authority - EFSA, Food and Agriculture Organization of the United Nations - FAO, \& World Health Organization - WHO. (2011a). State of the art on Total Diet Studies based on the replies to the EFSA/FAO/WHO questionnaire on national total diet study approaches. Supporting Publications, 206, 1-38. Retrieved from http:// www.efsa.europa.eu/en/supporting/doc/206e.pdf.

European Food Safety Authority - EFSA, Food and Agriculture Organization of the United Nations - FAO, \& World Health Organization - WHO. (2011b). Towards a harmonised Total Diet Study approach: a guidance document. EFSA Journal, 9(11), 1-66. Retrieved from http://www. efsa.europa.eu/en/efsajournal/doc/2450.pdf.

Food Standards Australia New Zealand - FSZANZ. (2011). The 23rd Australian Total Diet Study. Retrieved from http://www.foodstandards. gov.au/publications/Pages/23rdaustraliantotald5367.aspx

French agency for food, environmental and occupational health \& safety - ANSES. (2011). Second Total Diet Study (TDS 2). Report 1 - Inorganic contaminants, minerals, persistent organic pollutants, mycotoxins and phytoestrogens. Retrieved from http://anses.fr/sites/ default/files/documents/PASER2006sa0361Ra1EN.pdf

Health Canada (2009). Canadian Total Diet Study. Canada. Retrieved from http://www.hc-sc.gc.ca/fn-an/surveill/total-diet/index-eng.php

Instituto Brasileiro de Geografia e Estatística - IBGE. (2010). Pesquisa de Orçamentos Familiares 2008-2009 - aquisição alimentar domiciliar per capita - Brasil e grandes regiões. Retrieved from http://www.ibge. gov.br/home/estatistica/populacao/condicaodevida/pof/2008_2009_ aquisicao/pof20082009_aquisicao.pdf

Instituto Brasileiro de Geografia e Estatística - IBGE. (2011). Pesquisa de Orçamentos Familiares 2008-2009: análise do consumo alimentar pessoal no Brasil. Retrieved from http://www.ibge.gov.br/home/ estatistica/populacao/condicaodevida/pof/2008_2009_analise_ consumo/pofanalise_2008_2009.pdf

Llobet, J. M., Falcó, G., Casas, C., Teixidó, A., \& Domingo, J. L. (2003). Concentrations of arsenic, cadmium, mercury, and lead in common foods and estimated daily intake by children, adolescents, adults, and seniors of Catalonia, Spain. Journal of Agricultural and Food Chemistry, 51(3), 838-842. http://dx.doi.org/10.1021/jf020734q. PMid:12537467

Lombardi-Boccia, G., Aguzzi, A., Cappelloni, M., Di Lullo, G., \& Lucarini, M. (2003). Total-diet study: dietary intakes of macro elements and trace elements in Italy. The British Journal of Nutrition, 90(6), 1117-1121. http://dx.doi.org/10.1079/BJN2003997. PMid:14641971

Ministry of Agriculture and Forestry. (2011). 2009 New Zealand Total Diet Study: agricultural compound residues, selected contaminant and nutrient elements. Retrieved from http://www.foodsafety.govt. nz/elibrary/industry/total-diet-study.pdf. 
Muñoz, O., Bastias, J. M., Araya, M., Morales, A., Orellana, C., Rebolledo, R., \& Velez, D. (2005). Estimation of the dietary intake of cadmium, lead, mercury, and arsenic by the population of Santiago (Chile) using a Total Diet Study. Food and chemical toxicology: an international journal published for the British Industrial Biological Research Association, 43(11), 1647-1655. http://dx.doi.org/10.1016/j. fct.2005.05.006. PMid:15975702

Nasreddine, L., Hwalla, N., El Samad, O., LeBlanc, J.-C., Hamzé, M., Sibiril, Y., \& Parent-Massin, D. (2006). Dietary exposure to lead, cadmium, mercury and radionuclides of an adult urban population in Lebanon: a total diet study approach. Food Additives and Contaminants, 23(6), 579-590. http://dx.doi.org/10.1080/02652030500529452. PMid:16766457

Nasreddine, L., Nashalian, O., Naja, F., Itani, L., Parent-Massin, D., Nabhani-Zeidan, M., \& Hwalla, N. (2010). Dietary exposure to essential and toxic trace elements from a Total diet study in an adult Lebanese urban population. Food and chemical toxicology: an international journal published for the British Industrial Biological Research Association, 48(5), 1262-1269. http://dx.doi.org/10.1016/j. fct.2010.02.020. PMid:20176072

Sirot, V., Volatier, J. L., Calamassi-Tran, G., Dubuisson, C., Ménard, C., Dufour, A., \& Leblanc, J. C. (2009). Core food of the French food supply: second Total Diet Study. Food Additives and Contaminants, 26(5), 623-639. http://dx.doi.org/10.1080/02652030802695506. PMid:19680937
Turrini, A., \& Lombardi-Boccia, G. (2002). The formulation of the market basket of the Italian total diet 1994-96. Nutrition Research (New York, N.Y.), 22(10), 1151-1162. http://dx.doi.org/10.1016/ S0271-5317(02)00428-1.

World Health Organization - WHO. (1985). Global Environmental Monitoring System - guidelines for the study of dietary intakes of chemical contaminants. Switzerland: World Health Organization. Retrieved from http://www.who.int/foodsafety/publications/chem/ Guidelines_chem_contam.pdf.

World Health Organization - WHO. (1999). GEMS/Food total diet studies: report of a Joint USFDA/WHO. Kansas. Retrieved from http://apps. who.int/iris/bitstream/10665/66102/1/WHO_SDE_PHE_FOS_99.9.pdf

World Health Organization - WHO. (2002). GEMS/Food total diet studies: report of the 2nd International Workshop on Total Diet Studies. Brisbane. Retrieved from http://www.who.int/foodsafety/ publications/chem/en/tds_feb2002.pdf

World Health Organization - WHO. (2005). GEMS/Food total diet studies: report of 3rd International Workshop on Total Diet Studies. Paris. Retrieved from http://www.who.int/foodsafety/publications/ chem/TDS_Paris_en.pdf

World Health Organization - WHO. (2006). GEMS/Food Total Diet Studies: report on the 4th International Workshop on Total Diet Studies. Beijing. Retrieved from http://www.who.int/foodsafety/ publications/chem/TDS_Beijing_2006_en.pdf 